\title{
PSYCOLOGICAL CONDITIONS OF THE FORMATION OF PROFESSIONALLY ORIENTED RHETORICAL COMPETENCE OF FUTURE TEACHERS IN PEDAGOGICAL COLLEGES
}

\begin{abstract}
У статті актуалізовано проблему фрормування професійно орієнтованої риторичної компетентності майбутніх учителів у педагогічних коледжах відповідно до вимог сучасної освіти. Сфрормульовано визначення психологічних умов у результаті дослідження наукової та методичної літератури. Визначено психологічні умови формування риторичної компетентності у процесі фрахової підготовки студентів педагогічних коледжів до профресійної діяльності в результаті аналізу психолого-педагогічної та методичної літератури і концептуальних засад дослідження. Охарактеризовано студентський вік на основі вивчення науковоі та психологічної літератури. З'ясовано, що студентський вік є найбільш продуктивним і результативним у особистісному та професійному розвитку кожної людини. Зазначено, що саме у цьому віці формуються професійні світогляди якості майбутнього фрахівця, розвиваються професійні здібності та творчість майбутнього педагога, інтенсивно розвиваються інтелектуальні здібності та ціннісні орієнтації особистості. Доведено, що під час орормування профресійно орієнтованої риторичної компетентності у студентів потрібно враховувати індивідуально-психологічні особливості їхнього розвитку, які мають великий діапазон можливостей для результативної навчальної діяльності в педагогічних коледжах. Наголошується на важливості риторичної компетентності для майбутнього педагога, оскільки вона має професійне спрямування та застосовується насамперед для розв'язання навчально-виховних завдань. Установлено, що становлення майбутніх учителів як особистості в педагогічних коледжах відбувається паралельно з формуванням у них умінь і навичок, комплексу компетентностей, зокрема профресійно орієнтованої риторичної, тому викладачі мають враховувати психологічні та вікові особливості студентів як суб'єктів освітнього процесу. Визначено перспективи подальших досліджень у цьому напрямі. Ключові слова: професійно орієнтована риторична компетентність, майбутні
\end{abstract}

вчителі, педагогічні коледжі, психологічні умови, вікові особливості студентів.

The problem of the formation of professionally oriented rhetorical competence of future teachers in pedagogical colleges in accordance with the requirements of modern education is actualized in the article. The definition of psychological conditions as a result of research of scientific and methodological literature is formulated. The psychological conditions of formation of rhetorical competence in the process of professional training of students in pedagogical colleges for professional activity as a result of the analysis of psychological and pedagogical, methodological literature and as a result of the analysis of conceptual principles of the research are determined. The student's age is characterized based on the study of scientific and psychological literature. It has been found that the student's age is the most productive and efficient in each person's personal and professional development. It is stated that at this age professional outlooks of the quality of the future specialist are formed, professional abilities and creativity of the future teacher are developed, intellectual abilities and values of personality are intensively developed. It is proved that in the formation of professionally oriented rhetorical competence students' individual and psychological features of their development need to be taken into account, which have a large range of opportunities for effective educational activities in the pedagogical colleges. The importance of the rhetorical competence for the future teacher is focused on as it has a professional direction and is used primarily to solve educational problems. It is established that the formation of future teachers as an individual in the pedagogical colleges occurs in parallel with the formation of their skills, the complex of competences, in particular professionally oriented rhetorical competence, so college teachers should take into account the psychological and age characteristics of students as subjects of the educational process. The prospects for further researches in this area are identified.

Key words: professionally oriented rhetorical competence, future teachers, pedagogical colleges, psychological conditions, students' age characteristics. коледж»

Постановка проблеми у загальному вигляді. Відповідно до запитів сучасного суспільства й освіти зростають вимоги до майбутнього педагога, який має конструктивно й системно мислити, креативно виражати своє ставлення до світу, бути толерантним до думки іншого, готовим до гармонійної мовленнєвої взаємодії. Одна 3 умов розв'язання цього завдання - наявність в освітніх працівників риторичної компетентності, що є обов'язковим компонентом педагогічної майстерності. Завдяки володінню такою компетентністю педагог може виявити себе як переконливий мовець і досягти успіху в прооресійній сорері.

Становлення майбутніх учителів як особистості в педагогічних коледжах відбувається паралельно з формуванням у них умінь і навичок, комплексу компетентностей, зокрема професійно орієнтованої риторичної, тому викладачі мусять враховувати психологічні та вікові особливості студентів як суб'єктів освітнього процесу. Отже, висвітлення психологічних умов $€$ надзвичайно важливим аспектом нашого дослідження. 
Аналіз останніх досліджень і публікацій. У контексті нашого дослідження виявили, що психологічним умовам формування риторичної компетентності майбутніх фрахівців приділяли увагу такі науковці, як Н. Баран, М. Барахтян, Т. Дрозд, О. Корчова, В. Нагаєв, В. Нищета, Б. Савчук та iн. Проте питання виявлення психологічних умов, необхідних для фрормування профресійно орієнтованої риторичної компетентності майбутніх учителів у процесі фрахової підготовки у педагогічних коледжах, вивчене не досить.

Мета цієї статті - виявити психологічні умови формування просресійно орієнтованої риторичної компетентності майбутніх педагогів у процесі фрахової підготовки у педагогічних коледжах.

Виклад основного матеріалу. Дослідження наукової та методичної літератури підтверджують, що немає сучасного визначення понять «умова», «психологічна умова» та «педагогічна умова». Щодо поняття «умова», то в нашому дослідженні дотримуємось бачення Л. Виготського, який визначає поняття «умова» як: сукупність перемінних природних, соціальних, зовнішніх та внутрішніх впливів, що продукують фрізичний, психічний, моральний розвиток людини, її поведінку; виховання і навчання, формування особистості [2, с. 285].

Отже, під психологічними умовами логічно розуміти психологічне поняття, зміст якого складається 3 особливостей розвитку індивідуально-вікових особливостей та пізнавальних психічних процесів, які сприяють фоомуванню готовності майбутнього вчителя до професійної діяльності.

Психологія, на думку Б. Ананьєва, $є$ однією 3 наук, яка виявляється для педагогіки джерелом знань про ресурси та резерви людського розвитку і фракторів, що визначають зміни людської природи [1, с. 13]. Ось чому врахування психологічних умов є надзвичайно важливим під час формування професійно орієнтованої риторичної компетентності майбутніх учителів у педагогічних коледжах. Щоб допомогти студентам педагогічних коледжів досягти високих результатів у навчальній діяльності та профеесійному розвитку, необхідно знати їхні вікові, індивідуальні психологічні особливості та умови психічного розвитку.

Студентський період життя людини припадає на період пізньої юності або ранньої дорослості (15-19 років) студентів порівняно з іншими групами молоді. Як вважають Л. Подоляк і В. Юрченко, вирізняють такі риси цього віку, як: вищий освітній рівень, велике прагнення до змагань, висока соціальна активність, досить гармонійне поєднання інтелектуальної і соціальної зрілості [4, с. 42]. Таким чином, більшість студентів прагнуть отримати ґрунтовні знання, ссрормувати уміння і навички, набути професійних компетентностей, проявити себе активно в навчальній та науковій діяльності. Саме у студентському віці формується професійна майстерність, світоглядні цінності, особистість реалізує себе у багатьох соціальних ролях, навчаючись у педагогічному коледжі.
Отже, розглянемо особливості фрізичного, психосрізичного й когнітивного розвитку студентів. Л. Подоляк і В. Юрченко стверджують, що фрізичний розвиток стосується різноманітних аспектів фрізіологічних, сенсорних і рухових фрункцій організму. Він розпочинається з найпершої миті життя людини і досягає свого розквіту від 20 до 30 років, характеризується найвищим рівнем таких показників, як м'язова сила, швидкість реакції, моторна спритність і фрізична витривалість [4, с. 13]. Студенти фрізично готові до навчального навантаження, можуть виконувати довготривалі завдання, які сприяють розвитку просресійно орієнтованої риторичної компетентності майбутнього педагога.

Як відомо, мозок людини досягає фуункціональної зрілості на початку юності. Через те, що популяція нейронів уже повністю сорормована, подальше дозрівання нервової системи пов'язане лише 3 розгалуженням відростків у кожного нейрона, мієлінізацією нервових волокон і розвитком гліальних клітин, які відповідають насамперед за живлення нейтронів [4, с. 13].

До того ж Б. Ананьєв стверджував, що в юнацькому та ранньому дорослому віці існують складні кореляційні залежності між полем зору, об'єктом перспективної уваги та інформаційною ємністю чи короткостроковою пам'яттю. Кожен з цих компонентів кореляційної плеяди більш залежить від інших ії̈ компонентів, ніж безпосередньо від зовнішнього стимулу. Статистично доведені кореляційні погляди, отримані Л. Петровим (1971), який виявив у зоровій пам'яті підлітків комплекс залежностей між різними мнемічними фрункціями. Далеко не всі 3 них корелюють 3 будь-якою 3 мнемічною фуннкцією, однак усі вони без винятку корелюють з об'єктом пам'яті на слова [1, с. 47]. Крім того, досліди В. Андрєєвої 3 тими ж випробувальними показами, що аналогічні положення наявні в слуховій пам'яті, де центральне місце в кореляційній плеяді займає також об'єм словесної пам'яті. Формування професійно орієнтованої риторичної компетентності базується на запам'ятовуванні текстів, зразків літературних творів, виступів ораторів, відомих фрілософрів та провідних педагогів. Студенти часто готують доповіді, виступають на конференціях, де запам'ятовування великих блоків інсрормації просто їм необхідне.

Б. Ананьєв дослідив, що у процесі індивідуального розвитку аналітична діяльність великих півкуль головного мозку прогресує у відповідності до формування складних систем його синтетичної діяльності. Психолог додає, що саме синтетична діяльність забезпечує розширене відтворення потоків інсрормації, ії̈ впорядкування, вибір і організацію постійної взаємодії всіх каналів зв'язку 3 навколишнім середовищем [1, с. 36]. Формування професійно орієнтованої риторичної компетентності майбутнього вчителя відбувається в процесі відбору, впорядкування та відтворення інформації. Тому саме в студентському віці наявні найбільші можливості для результативного розвитку цієї профресійної компетентності. 
Вчені Л. Подоляк та В. Юрченко виділяють такі найважливіші нейрофрізіологічні особливості, які пов'язані з розвитком центральної нервової системи студента, як [4, с. 44]:

- найменший латентний (прихований) період реакції на будь-який вплив зовнішнього і внутрішнього подразника (у т. ч. і словесний сигнал), тобто найшвидше реагування на нього;

- оптимум абсолютної та розпізнавальної чутливості всіх аналізаторів;

- найбільша пластичність кори головного мозку та висока гнучкість в утворенні складних психомоторних та інших навичок;

- найбільший обсяг оперативної (короткочасної) пам'яті зорової і слухової модальності (є залежність динаміки розвитку мнемічних фрункцій від характеру діяльності людини; активна розумова діяльність сприяє вищим показникам пам'яті);

- високі показники уваги (рівень обсягу, переключення і вибірковості уваги поступово підвищується від 18 до 33 років);

- оптимум розвитку інтелектуальних срункції припадає на 18-20 років;

- найвища швидкість розв'язання вербальнологічних завдань (комплексний характер мисленнєвих операцій у разі високого рівня інтеграції різних видів мислення гнучкого переходу від образного до логічного та навпаки);

- інтенсивний розвиток усіх видів почуттів, підвищена емоційна чутливість до різних обставин навколишнього життя.

Таким чином, ці високі показники розвитку нервової системи та нейрофрізіологічної особливості роблять студентський період життя надзвичайно сприятливим для навчальної діяльності та профресійної підготовки майбутнього педагога.

Психолог А. Кузьминський також характеризує студентський вік найбільш сприятливими умовами для психологічного, біологічного та соціального розвитку. У цей період найшвидша швидкість пам'яті, реакції, пластичність у формуванні навичок. В особистості на цьому етапі допоміжними $€$ становлення характеру та інтелекту. Активно розвиваються морально-ціннісні й естетичні почуття. Швидко освоюються соціальні ролі дорослого (громадянські, профресійні та ін.). Досягається високий рівень розвитку фрізичних та інтелектуальних сил, активно зростають творчі можливості, збагачується емоційно-чуттєвий зміст [3, с. 114]. Тому саме, навчаючись у педагогічному коледжі, студенти мають максимальні можливості набути професійних компетентностей, зокрема професійно орієнтовану риторичну компетентність. Найвища швидкість пам'яті, реакції допомагають виконувати необхідні завдання для фрормування цієї компетентності. Крім того, пластичність у фрормуванні навичок сприяє фрормуванню професійно орієнтованої риторичної компетентності майбутніх учителів. Студенти також ефективно володіють теорією та практикою побудови профресійно-педагогічного мовлення на засадах істини, добра і краси, оскільки в цей період активно розвиваються моральноціннісні та естетичні почуття.

Важливим аспектом, як вважають Л. Подоляк і В. Юрченко, психічного розвитку людині в юнацькому періоді $\epsilon$ інтенсивне інтелектуальне дозрівання. Науковці виділяють такі показники інтелектуальної зрілості, як: широта розумового кругозору; гнучкість та багатоваріативність оцінок того, що відбувається; готовність приймати суперечливу інформацію; уміння усвідомлювати інформацію в термінах минулого (причини) і майбутнього (наслідки); орієнтація на виявлення суттєвих, об'єктивно значущих аспектів того, що відбувається; здатність бачити явище в контексті його цілісних зв'язків 3 іншими явищами, вміння мислити в категоріях ймовірного [4, с. 45]. Ці показники інтелектуального розвитку особистості в студентські роки сприяють розвитку професійних компетентностей, зокрема професійно орієнтованої риторичної компетентності. Формуючи зазначену компетентність, студент педагогічного коледжу навчається конструктивно і системно мислити, креативно виражати своє ставлення до світу, бути толерантним до думки іншого та готовим до гармонійної мовленнєвої взаємодії.

Висновки. Отже, студентський вік $є$ найбільш продуктивним і результативним у особистісному та професійному розвитку кожної людини. Саме у цьому віці фрормуються профеесійні світогляди якості майбутнього фрахівця, розвиваються профресійні здібності та творчість майбутнього педагога, інтенсивно розвиваються інтелектуальні здібності та ціннісні орієнтації особистості. Тому для формування профресійно орієнтованої риторичної компетентності у студентів потрібно враховувати індивідуально-психологічні особливості їхнього розвитку, які мають великий діапазон можливостей для результативної навчальної діяльності в педагогічних коледжах.

Проведене дослідження не вичерпує всіх аспектів проблеми формування професійно орієнтованої риторичної компетентності майбутніх учителів у педагогічних коледжах. Подальшого дослідження потребує розробка та обґрунтування моделі форомування профресійно орієнтованої риторичної компетентності та розробка навчального і методичного забезпечення.

\section{БІБЛІОГРАФІЧНИЙ СПИСОК:}

1. Ананьев Б.Г. Избранные психологические труды. В 2-х т. Т. II / Под ред. А.А. Бодалева и др. Москва : Педагогика, 1980. 288 с.

2. Выготский Л.С. Педагогическая психология. Москва : Педагогика, 1991. 480 с.

3. Кузьмінський А.І. Педагогіка вищої школи : навчальний посібник. Київ : Знання, 2005. 486 с.

4. Подоляк Л.Г., Юрченко В.І. Психологія вищої школи : підручник. 2-е вид. Київ : Каравела, 2008. 352 c. 